\title{
Erratum to: Counter-flow suggests transport of dantrolene and 5-OH dantrolene by the organic anion transporters 2 (OAT2) and 3 (OAT3)
}

\author{
Birgitta C. Burckhardt ${ }^{1}$ Maja Henjakovic ${ }^{1,2}$ - Yohannes Hagos ${ }^{1,3}$. \\ Gerhard Burckhardt ${ }^{1}$
}

Published online: 26 November 2016

(C) Springer-Verlag Berlin Heidelberg 2016

Erratum to: Pflugers Arch - Eur J Physiol

DOI 10.1007/s00424-016-1894-6

The original publication of this paper contains a mistake.

The correct image of figure 3 is shown below:

The online version of the original article can be found under doi:http://dx. doi.org/10.1007/s00424-016-1894-6.

\footnotetext{
Birgitta C. Burckhardt

birgitta.burckhardt@med.uni-goettingen.de

1 Institute of Systemic Physiology and Pathophysiology, University Medical Center Göttingen, Humboldtallee 23,

37073 Göttingen, Germany

2 Department of Internal Medicine, University Medical Center Cologne, Kerpener Str. 62, 50937 Cologne, Germany

3 PortaCellTec Biosciences GmbH, Humboldtallee 23, 37073 Göttingen, Germany
} 
a

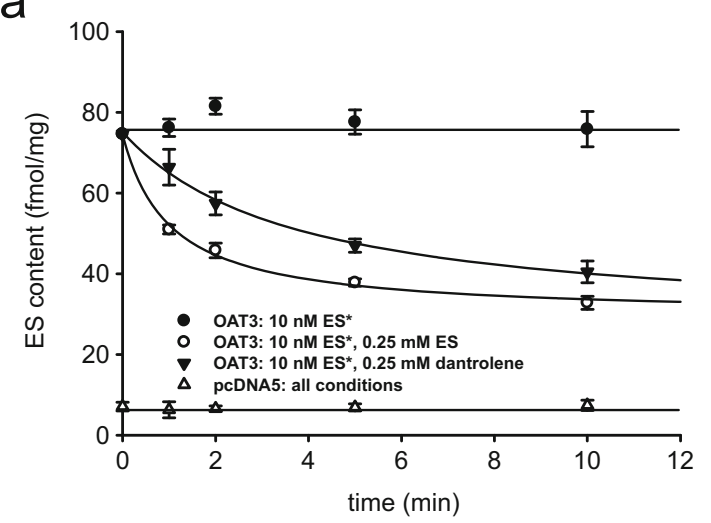

C

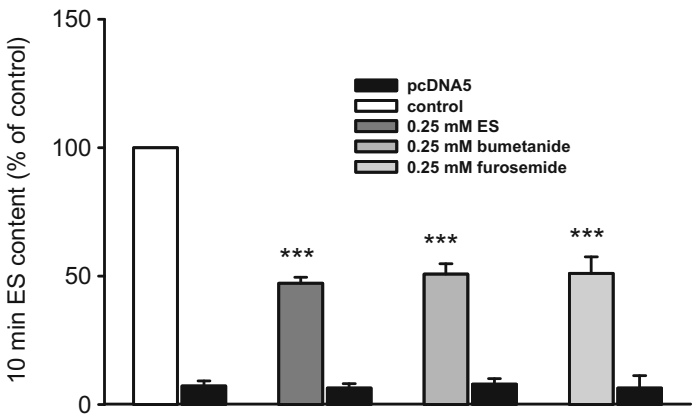

Fig. 3 Counter-flow experiments on OAT3. a Time course of ES efflux of OAT3- and pcDNA5-transfected HEK293 cells in the absence (filled circle) and presence of $0.25 \mathrm{mM}$ ES (unfilled circle) and $0.25 \mathrm{mM}$ dantrolene (filled triangle). OAT3 (filled circle, unfilled circle, filled triangle)- and pcDNA5 (unfilled triangle)-transfected HEK293 cells were incubated for $60 \mathrm{~min}$ at $37^{\circ} \mathrm{C}$ in solutions containing $10 \mathrm{nM}$ $\left[{ }^{3} \mathrm{H}\right] \mathrm{ES}$. After a wash-out, cells were incubated in $10 \mathrm{nM}\left[{ }^{3} \mathrm{H}\right] \mathrm{ES}$ minus or plus un-labeled $0.25 \mathrm{mM}$ ES or dantrolene. At the time indicated, the $\left[{ }^{3} \mathrm{H}\right]$ ES content of the cells was measured. b Specificity of counter-flow. Cells were incubated for $60 \mathrm{~min}$ at $37^{\circ} \mathrm{C}$ in solutions containing $10 \mathrm{nM}$ $\left.{ }^{3} \mathrm{H}\right] \mathrm{ES}$. Afterwards, cells were incubated for $10 \mathrm{~min}$ in solutions containing $10 \mathrm{nM}\left[{ }^{3} \mathrm{H}\right] \mathrm{ES}$ either in the absence (control) or presence of the indicated compounds. After wash-out in ice-cold PBS, the $\left[{ }^{3} \mathrm{H}\right] \mathrm{ES}$ content was determined. ES, dantrolene, 5-OH dantrolene, ES, and b

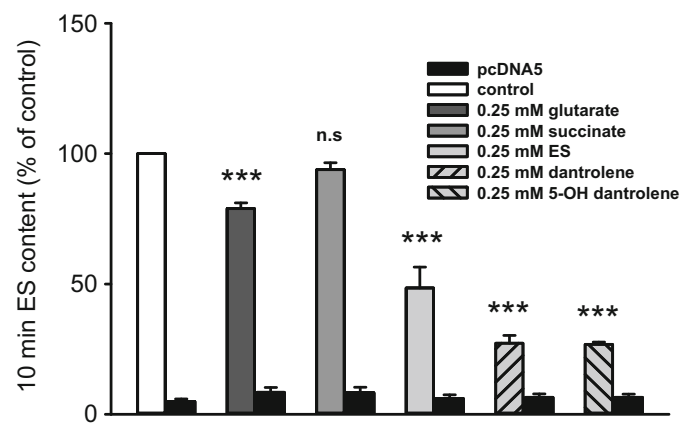

d

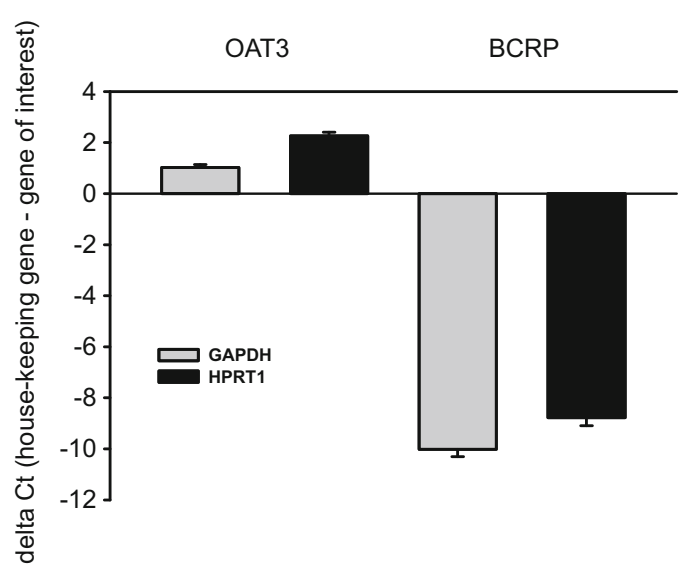

glutarate, each to a different extent, stimulated loss of ES, whereas succinate did not reduce ES content. ES content of pcDNA5-transfected cells was unaffected by the above treatments. $\mathbf{c}$ Counter-flow induced by known OAT3 substrates. Experiments were performed as described in $\mathbf{b}$. Concentrations of bumetanide and furosemide were $0.25 \mathrm{mM}$ each; experiments presented in $\mathbf{a}-\mathbf{c}$ were performed in triplicate on consecutive cell passages. d Endogenous mRNA expression of BCRP in HEK293 cells. mRNA coding for BCRP was analyzed in nontransfected HEK293 cells by real-time PCR. As a positive control, OAT3 mRNA from OAT3-transfected HEK293 cells was used. Data are means $\pm \mathrm{SE}$ and expressed as $\Delta \mathrm{Ct}$ values. Negative bars (BCRP) indicate lower, positive bars (OAT3) indicate higher mRNA content as compared to the housekeeping genes (HPRT1, GAPDH) 